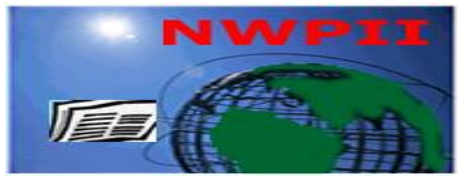

American Journal of

Biomedical Sciences

ISSN: 1937-9080

nwpii.com/ajbms

\title{
A Novel Role of Vitamin $K$ in Amelioration of Experimental Induced Ulcerative Colitis in Rats
}

\author{
EMAN R. ABOZAID, M.D and WESAM M. R. ASHOUR, M.D*
}

Medical Physiology Department, Faculty of Medicine, Zagazig university-Egypt

*Corresponding Author

Wesam M. R. Ashour

Medical Physiology Department,

Faculty of Medicine,

Zagazig University

Egypt

E-mail: wesam_ashour@yahoo.com

Received:13 October 2019; | Revised:05 November 2019; | Accepted:05 March 2020

\section{Abstract}

Background: The presence of inflammatory mediators and free radicals are well-known features in the pathogenesis of ulcerative colitis (UC). Patients with ulcerative colitis often exhibit vitamin K (vit K) deficiency. Some studies have been discussed role for vit $\mathrm{K}$ as anti-inflammatory and antioxidant factor in other tissues, but the modulatory role of vit $\mathrm{K}$ supplementation by different routes in ulcerative colitis is unclear, with its antioxidant capacity and anti-inflammatory activity, vit $\mathrm{K}$ would be expected to reduce injury from ulcerative colitis. The aim of this study is to verify the role of vit $\mathrm{K}$ in the pathophysiology of intestinal inflammation using acetic acid induced ulcerative colitis model in rats. In addition, the efficiency of vit $\mathrm{K}$ injection in comparison to oral vit $\mathrm{K}$ supplementation in such condition was investigated.

Methods: 24 adult male albino rats were divided to 4 main groups $(n=6)$ : group (A) control intact received saline intrarectally and take water by gavage, (B) acetic acid-induced colitis group injected with 2 $\mathrm{ml}$ acetic acid (4\%) intra rectally and take water by gavage), (C) acetic acid-induced colitis with oral vit $\mathrm{K}$ $(1.6 \mathrm{mg} / \mathrm{kg} / \mathrm{d})$ and (D) acetic acid-induced colitis injected with vit $\mathrm{K}(1.6 \mathrm{mg} / \mathrm{kg} / \mathrm{d})$ intraperitoneally (ip), vit $\mathrm{K}$ was given $24 \mathrm{~h}$ after induction of colitis and persisted for 8 consecutive days. Disease activity was evaluated biochemically by measuring proinflammatory cytokine levels and oxidative stress markers in colonic tissue sample, Ulcer index, severity of inflammation and histological changes were recorded after the end of the treatment regimen.

Results: Acetic acid induced colitis group B showed atrophy of lining mucosa with areas of ulceration, with inflammatory cell infiltration detected by microscopic examination and evaluated by injury score index, in addition to increased levels of tumor necrosis factor- $\alpha$ (TNF- $\alpha$ ), interleukin-1 $\beta$ (IL-1 $\beta$ ), interleukin-6 (IL-6), myeloperoxides (MPO), malondialdehyde (MDA), and decreased levels of glutathione peroxidase (GPX) and superoxide dismutase (SOD) when compared with control group A; whereas vitamin K administration in group $\mathrm{C}$ and D significantly suppressed TNF- $\alpha$, IL-1 $\beta$, IL-6 production, increased GPX and SOD and decreased the score injury index when compared to group B. Moreover, group D showed more 
significant decreased in TNF- $\alpha$, IL-1 $\beta$, IL-6, increased GPX and SOD and decreased the score injury index when compared with group $\mathrm{C}$.

Conclusion: Our study proposes that vit $\mathrm{K}$ has effective anti-inflammatory and antioxidant role in modulating ulcerative colitis and may be a promising adjuvant therapeutic option for ulcerative colitis, with higher effectiveness of injectable form than oral supplementation.

Keywords: Vitamin K,Ulcerative colitis, Rats

\section{Introduction}

Ulcerative colitis (UC) is a chronic inflammatory bowel disease of the large intestine. The etiology of ulcerative colitis is not fully understood, however, decreased antioxidant capacity and increased free radical production are well-known features of inflammatory bowel disease (IBD). Reactive oxygen species and subsequent lipid peroxidation decrease cellular antioxidant capacity, which result in prominent colonic inflammation. Excessive inflammation and oxidative stress have pivotal roles in the pathogenesis of UC disease [1-4]. Inflammatory mediators are known to be secreted from migrated granulocytes in the inflamed mucosa in IBD ${ }^{[5,6]}$. It is widely accepted that both $\mathrm{UC}$ and $\mathrm{CD}$ are caused by inflammation-related cytokine-driven mixed infiltrates in the intestinal mucosa ${ }^{[7]}$. Some proinflammatory cytokines such as TNF- $a$, IL-1b, IL-6, and IL-17 also play crucial roles in disease pathogenesis [8-10]. Inhibition of lipid peroxidation or scavenging of oxygen free radicals would a rationale for therapeutic modulation with antioxidants ${ }^{[11-13]}$.

There are two types of naturally occurring vit $\mathrm{K}$ : phylloquinone (K1), which is synthesized in plants, and menaquinone (MK-n or K2) which is mainly produced by microorganisms. Significant amounts of menaquinones are synthesized by intestinal flora in the lower intestine and absorbed. After absorption from the intestine, vit $\mathrm{K}$ is transported to the liver by triglyceride-rich lipoprotein chylomicrons to activate K-dependent proteins. vit $\mathrm{K}$ is essential for both blood coagulation and bone metabolism in mammals. vit $\mathrm{K}$ acts as a cofactor for microsomal -glutamyl carboxylase in the posttranslational synthesis of carboxyglutamic acid from the glutamic acid residues contained in vit $\mathrm{K}$ dependent precursor proteins ${ }^{[11,12]}$.

Vitamin $\mathrm{K}$ has recently been shown to suppress inflammation by inhibiting the production of IL-6 in human macrophages and fibroblasts ${ }^{[13,14]}$. In another study, the antioxidant effect of vit $\mathrm{K}$ has been revealed by inhibiting glutathione depletionmediated oxidative cell death in primary cultures of immature fetal cortical neurons and oligodendrocyte precursors and completely blocks free radical accumulation and cell death. ${ }^{[15]}$. In addition, dietary supplementation of vit $\mathrm{K} 1$ has been shown to suppress the lipopolysaccharide-induced hepatic inflammatory process in rats ${ }^{[13]}$.

Although these reports suggest that vit $\mathrm{K}$ has anti-inflammatory and antioxidant properties, it is not known if vit $\mathrm{K}$ can modulate intestinal inflammation, hence, we designed the current study to assess the possible modifying effect (s) of vit $\mathrm{K}$ supplementation with different routes of administration on acetic acid-induced ulcerative colitis in adult male rats.

\section{Materials and Methods}

This study was conducted in the scientific and medical research center (ZSMRC) in Faculty of Medicine, Zagazig University in the period from 2nd to 25 th of January 2019, This study protocol was approved by the Ethics Committee of Medicine Faculty, Zagazig University. The study was performed on 24 adult male albino rats 12-15 weeks old weighing 190-230 g. Rats were obtained from the animal house of Faculty of Veterinary Medicine, Zagazig University.. Animals were kept in clean wire cages at comfortable temperature with 12-hour light/dark cycles and with free access to water. After a two weeks' adaptation period the animals were randomized into four main groups: 


\subsection{Animal grouping}

Adult male rats were randomly divided into four groups (6 rats in each) as follows: Group (A): control group without induction of colitis (intact group) and vehicle treated in which rats received water, orally (gavage). Group (B): acetic acidinduced colitis, injected with $2 \mathrm{ml}$ acetic acid (4\%) intra rectally), Group (C) induced colitis in addition to treatement by vit $\mathrm{K} 1(1.6 \mathrm{mg} / \mathrm{kg})$ orally (gavage) Phylloquinone (K1) $100 \mathrm{mg}$ ampoul (CAS Number 84-80-0), and group (D): induced colitis with treatment with vit $\mathrm{k} 1(1.6 \mathrm{mg} / \mathrm{kg})$ i.p, in both treated groups vit $\mathrm{K}$ was given $24 \mathrm{~h}$ after induction of colitis and persisted for 8 consecutive days., the dose was selected as described before with some modification $^{[16]}$.

\subsection{Induction of colonic inflammation in rats}

All animals were fasted overnight, with access to water ad libitum, the rats anesthetized by ether inhalation. Before induction of colitis, a polypropylene tube with $2 \mathrm{~mm}$ diameter was inserted through the rectum into the colon to a distance of $8 \mathrm{~cm}$. A solution of two $\mathrm{ml}$ acetic acid $(4 \%)$. The rats were maintained in a Trendelenburg position for $30 \mathrm{sec}$ to prevent leakage of the intracolonic instillation ${ }^{[17]}$.

At the end of the study, all rats were sacrificed by cervical dislocation. The last $8 \mathrm{~cm}$ of the colon was excised, opened longitudinally and rinsed with saline solution. Then the distal colon were weighed and scored the mucosal lesions macroscopically. Tissue samples were taken for histologic evaluation of the lesions under light microscopy.

\subsection{Assessment of colon macroscopic damage}

A segment of the colon, $8 \mathrm{~cm}$ in length and 3 $\mathrm{cm}$ proximal to the anus was excised, opened longitudinally and washed by saline buffer. These specimens were weighed. A pathologist who was unaware of the experimental conditions recorded macroscopic and histological damages. The criteria for macroscopic evaluation relied on a previously validated scoring system $(0-4)^{[18]}$. The scores were: $0=$ no ulcer; $1=$ mucosal erythema only; $2=$ mild mucosal edema, slight bleeding or slight erosion; $3=$ moderate edema, erosions or bleeding ulcers; and $4=$ severe ulceration, edema and tissue necrosis. Ulcer area was measured using scaled surgical transparent tape, which was fixed to a light and transparent sheet. Each cell on the tape was $1 \mathrm{~mm} 2$ in area and the number of cells covering the ulcerated area of each specimen was counted. Ulcer index was measured by summing the ulcer score and the ulcer area of each tissue specimen. Ulcer index was calculated according to the following formula: $\mathrm{UI}=\mathrm{UN}+\mathrm{US}+\mathrm{UA} \times 10-1$, where $\mathrm{UI}=$ ulcer index, $\mathrm{UN}=$ ulcer number, $\mathrm{US}=$ ulcer score and $\mathrm{UA}=$ ulcer area.

\subsection{Assessment of colon histological damage}

Colon tissues were separately fixed in 10\% formalin, dehydrated, paraffin embedded, processed, sectioned as $4 \mu \mathrm{m}$-thick sections, and stained with haematoxylin and eosin (HE). Inflammation severity $(0=$ none, $1=$ slight, $2=$ =moderate, and $3=$ severe) was assessed in HE-stained, coded sections using a validated scoring scheme described before with some modifications ${ }^{[19]}$. The stained sections of colon were examined for any inflammatory changes like infiltration of the cells, necrotic foci and damage to tissue structures like payer's patches, crypt-abscess, and damage to nucleus. Crypitis, and goblet cells depletion and also inflammatory cells infiltrates in the lamina propria and colonic wall were estimated.

\subsection{Biochemical studies}

\subsubsection{Tissue myeloperoxidase activity Myeloperoxidase (MPO)}

Activity was determined by a modification of the O-dianisidine method. All measurements were carried out in duplicate. One unit of MPO was defined as vitamin-tahan_Layout 1 that giving an increase in absorbance of $0.001 \mathrm{~nm}$ per minute, and specific activity is reported as $\mathrm{U} / \mathrm{mg}$ protein.

\subsubsection{Tissue Malondialdehyde measurements (MDA)}

Can be detected in quantifiable amounts with the thiobarbituric acid reactive species (TBARS) assay. We obtained measurements of TBARS according to Ohkawa et al. ${ }^{[20]}$ Colonic tissues were homogenized in ice-cold 10\% trichloroacetic acid (TCA) solution and then centrifuged. The supernatant portion was mixed with equal volume of TBARS $(0.67 \%)$ and heated at $90^{\circ} \mathrm{C}$ for 15 
minutes. The TBARS were measured in $\mathrm{nmol} / \mathrm{mg}$ protein according to absorbance at $532 \mathrm{~nm}$.

\subsubsection{Tissue Superoxide dismutase (SOD) activity}

According to the method described before ${ }^{[21]}$. This method uses xanthine and xanthine oxidase to generate superoxide radicals. Superoxide dismutase activity is expressed as $\mathrm{U} / \mu \mathrm{g}$ protein.

\subsubsection{Tissue glutathione peroxidase (GPx) determination}

Estimation of GPx content follows the method of ${ }^{[21]}$. The intestinal sample was homogenized in 2 $\mathrm{mL}$ of $50 \mathrm{mMTris}-\mathrm{HCl}$ buffer, the contents of GPX were given as $\mathrm{U} / \mu \mathrm{g}$ protein

2.5.5 The levels of rat colonic tissue tumour necrosis factor (TNF) - $\alpha$, interleukin (IL)-1 $\beta$ and IL-6

With commercially available enzyme immunoassay kits (enzyme-linked immunosorbent assay [ELISA], Analyses of all samples, standards and controls were run in duplicate. Cytokine activities were expressed as $\mathrm{pg} / \mathrm{mg}$ protein.

\subsection{Statistical analysis}

The values were expressed as mean $\pm \mathrm{SD}$ and analyzed using version 18 SPSS program (SPSS Inc. Chicago, IL, USA). One way analysis of variance
(ANOVA) was used followed by student-least significant differences (LSD) test to compare statistical differences between groups. $\mathrm{P}$ value less than 0.05 was considered to be significant.

\section{Results}

\subsection{Effect of vitamin $K$ treatment on biochemical measures}

The present study showed that intra -rectal administration of acetic acid significantly increased MDA , MPO, TNF $\alpha$, IL-1 $\beta$ and IL-6 levels $(\mathrm{p}<0.001)$ while significantly decreased SOD and GPX levels $(p<0.001)$ in group B (acetic acidinduced colitis group) in comparison to those of group A (normal control group) (Table 1).

On the other hand, it was found that oral vitamin. $\mathrm{K}$ administration resulted in a significant decrease in MDA, MPO, TNF $\alpha$, IL-1 $\beta$ and IL-6 levels $(p<0.01)$ but significantly increased SOD and GPX levels $(\mathrm{p}<0.05, \mathrm{p}<0.01$ respectively) in group $\mathrm{C}$ (acetic acid-induced colitis treated by oral vit. K group) compared to those of group B (Table 1).

Moreover, in group D (acetic acid-induced colitis treated by ip vit. $\mathrm{K}$ group) vit. $\mathrm{K}$ injection resulted in a significant decrease in MDA, MPO, TNF $\alpha$, IL-1 $\beta$ and IL-6 levels $(p<0.001)$ but significantly increased SOD and GPX levels $(\mathrm{p}<0.001)$ when compared with those of group B and group $\mathrm{C}$ (Table 1).

Table 1: Colonic MDA, MPO, SOD, GPX, TNF- $\alpha$, IL-1 $\beta$ and IL-6 in all studied groups

\begin{tabular}{|c|c|c|c|c|c|}
\hline \multicolumn{2}{|c|}{ Parameters } & $\begin{array}{l}\text { Group A } \\
\text { ( control) }\end{array}$ & $\begin{array}{l}\text { Group B } \\
\text { (UC) }\end{array}$ & $\begin{array}{c}\text { Group C } \\
\text { (UC treated by } \\
\text { oral vit. K) } \\
\end{array}$ & $\begin{array}{c}\text { Group D } \\
\text { (UC treated by ip vit. } \\
\text { K) }\end{array}$ \\
\hline $\begin{array}{c}\text { MDA (nmol/g } \\
\text { protein }\end{array}$ & $\begin{array}{l}\bar{X} \pm \\
\text { SD }\end{array}$ & $4.11 \pm 1.1$ & $8.11 \pm 0.98^{a^{* * *}}$ & $6.62 \pm 0.84^{b^{* *}}$ & $4.67 \pm 0.83^{b^{* * * *} \mathrm{c}^{* * * *}}$ \\
\hline $\begin{array}{c}\text { MPO } \\
\text { (U/ g protein) } \\
\end{array}$ & $\begin{array}{l}\bar{X} \pm \\
\text { SD }\end{array}$ & $19.51 \pm 3.39$ & $51.45 \pm 3.21^{a^{* * * *}}$ & $44.46 \pm 2.66^{b * *}$ & $32.25 \pm 4.744^{b^{* * * *} \mathrm{c}^{* * * *}}$ \\
\hline 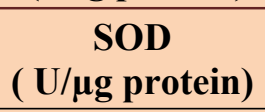 & $\begin{array}{l}\bar{X} \pm \\
\text { SD }\end{array}$ & $4.09 \pm 0.18$ & $2.94 \pm 0.28^{a^{* * * *}}$ & $3.26 \pm 0.38^{b^{*}}$ & $3.84 \pm 0.16 b^{b^{* * * *} \mathfrak{c}^{* * * *}}$ \\
\hline $\begin{array}{c}\text { GPX } \\
(\mathrm{U} / \mu \mathrm{g} \text { protein })\end{array}$ & $\begin{array}{l}\bar{X} \pm \\
\text { SD }\end{array}$ & $132.06 \pm 5$ & $72.45 \pm 3.79^{a * * *}$ & $80.65 \pm 6.73^{b^{* * *}}$ & $118.76 \pm 6.44^{b * * *} \mathbf{c}^{* * *}$ \\
\hline $\begin{array}{c}\text { TNF } \alpha \\
\text { (pg/mg tissue ) }\end{array}$ & $\begin{array}{l}\bar{X} \pm \\
\text { SD }\end{array}$ & $24.55 \pm 3.1$ & $86.37 \pm 5.55^{a^{* * * *}}$ & $78 \pm 3.97^{b^{* *}}$ & $34.62 \pm 4.20^{b^{* * * *} c^{* * * *}}$ \\
\hline $\begin{array}{l}\text { IL-1及 (pg/ mg } \\
\text { tissue) }\end{array}$ & $\begin{array}{l}\bar{X} \pm \\
\text { SD }\end{array}$ & $39.64 \pm 3.93$ & $81.65 \pm 3.38^{a^{* * *}}$ & $73.94 \pm 4.83^{b * *}$ & $49.50 \pm 3.822^{b^{* * * *} c^{* * * *}}$ \\
\hline $\begin{array}{c}\text { IL-6 } \\
\text { (pg/mg tissue) }\end{array}$ & $\begin{array}{l}\bar{X} \pm \\
\text { SD }\end{array}$ & $37.50 \pm 3.72$ & $93.09 \pm 4.67^{\mathrm{a} * * *}$ & $84.25 \pm 5.70^{b^{* *}}$ & $60.75 \pm 3.69^{b^{* * * *} c^{* * * *}}$ \\
\hline
\end{tabular}


$\mathrm{a}=$ Significant versus group $\mathrm{A}, \mathrm{b}=$ Significant versus group $\mathrm{B}, \mathrm{c}=$ Significant versus group $\mathrm{C} . *=\operatorname{significant}(\mathrm{P}<0.05)$; $* *=$ significant $(\mathrm{P}<0.01) ; * * *=$ significant $(\mathrm{P}<0.001)$

\subsection{Effect of vit $K$ treatment on histopathological studies and injury score index}

Acetic acid induced atrophy of lining mucosa with areas of ulceration, marked goblet cell depletion and transmural infiltration with inflammatory cells in form of lymphocytes, plasma cells and machrophages with sub mucosal edema with destruction of intestinal crypts (Figure 1.B; table 2) when compared to control Figure 1.A; table 2). Oral treatment with vit. K showed some

improvement of the degree of ulcerative colitis and regeneration of lining mucosa with decrease inflammatory cells infiltrate limited to mucosa (Figure 2.A; table 2), Moreover, IP injection of vit. $\mathrm{K}$ led to marked improvement in the degree of colonic lesions with regeneration of lining mucosa with prominent goblet cells and decrease inflammatory cells infiltrate limited to mucosa with free sub mucosa (Figure 2.B, table 2).

Table 2: Histopathological scoring of colonic damage

\begin{tabular}{|c|c|c|c|c|c|}
\hline Pare & & $\begin{array}{l}\text { Group A } \\
\text { ( control) }\end{array}$ & $\begin{array}{l}\text { Group B } \\
\text { (UC) }\end{array}$ & $\begin{array}{c}\text { Group C } \\
\text { (UC treated by oral } \\
\text { vit. K) }\end{array}$ & $\begin{array}{c}\text { Group D } \\
\text { (UC treated by ip vit. } \\
\text { K) }\end{array}$ \\
\hline $\begin{array}{c}\text { colonic injury } \\
\text { score }\end{array}$ & $\bar{X} \pm$ SD & $\mathbf{0}$ & $7.12 \pm 0.83^{a^{* * * *}}$ & $4.87 \pm 0.83^{b^{* * *}}$ & $2.37 \pm 0.52^{b^{* * * *} c^{* * * *}}$ \\
\hline
\end{tabular}

$\mathrm{a}=$ versus group $\mathrm{A} ; \mathrm{b}=$ versus group $\mathrm{B} ; \mathrm{c}=$ versus group $\mathrm{C} *=\operatorname{significant}(\mathrm{P}<0.05) ; * *=\operatorname{significant}(\mathrm{P}<0.01) ; * * *=$ significant $(\mathrm{P}<0.001)$
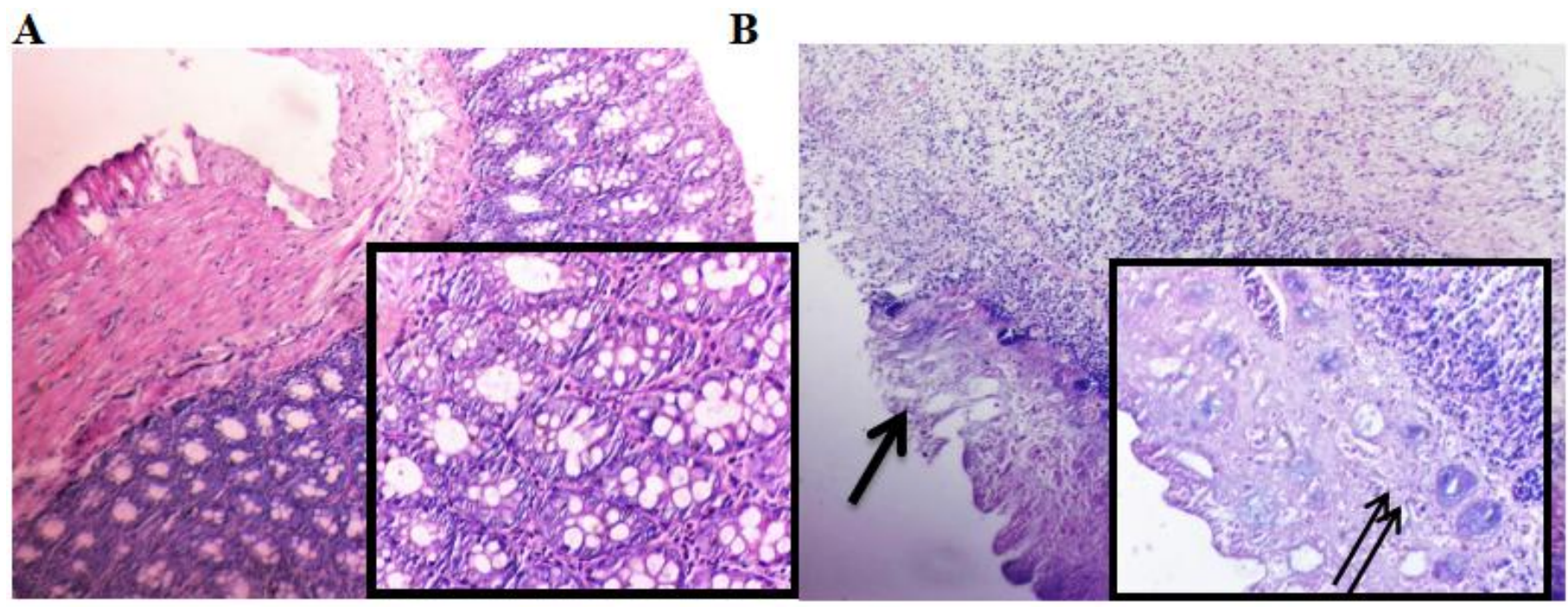

Figure 1: Histological Section in the intestine of control group (FIG.1.A) showed normal histology well-formed intestinal gland with intact goblet cells no ulceration or inflammation. Inflammatory score 0 , section from rat intestine with acetic acid-induced colitis (FIG.1.B) showing ulceration of lining mucosa (arrow), marked goblet cell depletion and transmural infiltration with marked inflammatory cells in form of lymphocytes, plasma cells and machrophages (double arrows) with sub-mucosal edema with destruction of intestinal crypts. Inflammatory score 8 (H\&E X200, inset X400). 


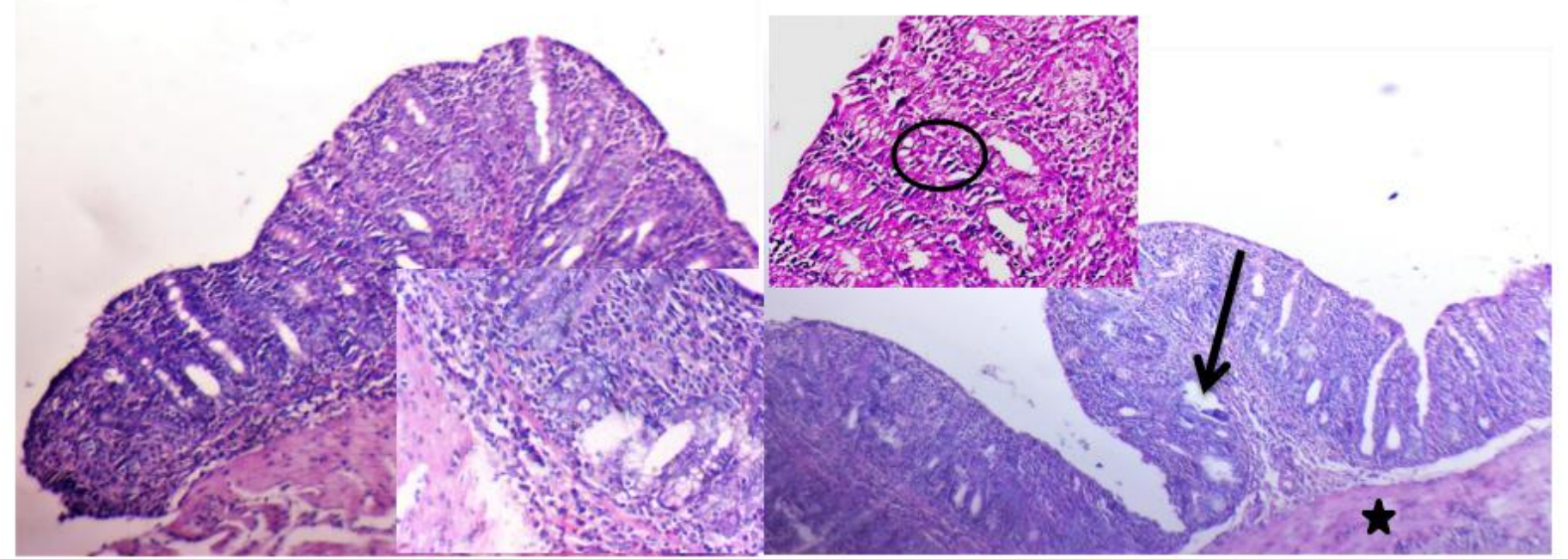

Figure 2: Histological section in rat intestine (UC treated by oral vit. K) (Fig. 2.A), showing regeneration of lining mucosa (arrow) with decrease inflammatory cells infiltrate limited to mucosa and submucosa. Inflammatory score 4, section in rat intestine (UC treated by ip vit. K (Fig.2.B), showing regeneration of lining mucosa (arrow) with prominent goblet cells (circle) and decrease inflammatory cells infiltrate limited to mucosa with free submucosa (star). Inflammatory score 2 (H\&E x200 inset X400).

\section{Discussion}

We studied the role of vit $\mathrm{K}$ supplementation in the pathophysiology of intestinal inflammation by using a model of acetic acid induced colitis. In addition, we evaluated the difference between effect of vit $\mathrm{K}$ injection and oral vit $\mathrm{K}$ supplementation on cytokine production and oxidative stress markers. In the present study, acetic acid induced colitis led to destruction of colon structure and mucosal barrier by chemical injury, increased vessel permeability, increase inflammatory cell infiltration, inflammatory mediator levels, and oxidative stress markers, this coincide with other studies on similar models ${ }^{[16,22]}$. On the other hand, we found that histological features of colitis were improved in rats treated with vit K- orally and parenteral with more significant improvement of injury score index concerning parenteral rout.

We proved that supplementation of vit $\mathrm{K}$ decrease colonic oxidative damage in rats with colitis, as vit $\mathrm{K}$ supplementation decreased the levels of MPO and MDA; a good indicator of lipid peroxidation. Increased lipid peroxidation products in intestinal tissue can start a vicious cycle that creates reactive metabolites, which deplete the ncellular antioxidants such as vitamin $\mathrm{E}$ and $\mathrm{C}$ and finally worsen inflammation and ulceration ${ }^{[26,27]}$

Our study also showed that treatment with vit $\mathrm{K}$ increased the Gpx and SOD levels. Gpx is involved in many mechanisms including, prevention of free radicals-induced damage, the synthesis and repair of DNA, recycling of vitamins $\mathrm{C}$ and $\mathrm{E}$ and improve their antioxidant activity, in addition to its role in detoxification ${ }^{[24]}$

In addition, vit $\mathrm{K}$ exerts an immunosuppressive effect and anti-inflammatory effects through the suppression of IL- 6 production, IL- $1 \beta$ and TNF $-\alpha$. The protective effect of vit $\mathrm{K}$ on acetic acid-induced colitis in rats was well confirmed by the histopathological studies. The results obtained from vit $\mathrm{K}$ treated acetic acid-induced colitis in the present study, is in well correlation with previous studies $[21,25]$

In the present study, we declared that vit $\mathrm{K}$ administered orally and by injection significantly inhibited the activity of lipid peroxides in the colonic tissue. However vit $\mathrm{K}$ injection has better result on improvement of condition and this coincide with the concept of malabsorption in that disease which affect vit $\mathrm{K}$ and other vitamin absorption, some studies mentioned that UC is 
associated with significant alterations in the function of the small intestine as manifested by a decrease in the absorption of fluid and nutrients and an increase in permeability ${ }^{[26-28]}$. We confirmed this concept by our result, as the weaker effect of oral vit $\mathrm{K}$ in comparison to parenteral vit $\mathrm{K}$ is due to the possible malabsorptive state, this concept of malabsorption in UC state can be affected by local inflammation that leads to undernutrition and/or malabsorption ${ }^{[29-32]}$.

In agreement with our study, The antioxidant and antiinflammatory effects of vit $\mathrm{K}$ have been also presented in some previous studies, A recent results demonstrating exacerbation of colitis due to a vit K-deficient diet associated with increased IL-6 expression, moreover, vit $\mathrm{K}$ deficiency is associated with increased severity of chrons disease [33]. Impaired suppression of IL- 6 by a K-deficient diet may constitute a mechanism for the exacerbation of colitis. In addition, the correlation between inflammation and vit $\mathrm{K}$ status has been reported for some inflammatory diseases; vit $\mathrm{K}$ treatment was found to reduce the severity of rheumatoid arthritis in mice and humans ${ }^{[34,35]}$.

Moreover, Reddi et al. ${ }^{[14]}$ previously showed that vit $\mathrm{K}$ treatment decrease lipopolysaccharide induced IL-6 production in cultured human fibroblasts [36]. IL-6 has been shown to play a crucial role in the development of colitis; injection of the IL-6 receptor antibodies ameliorates murine colitis $[37,38]$. Moreover, expression of Il-6 mRNA was significantly lower in the splenocytes cultured in vitro with vit $\mathrm{K}$ than that in those cultured without vit $\mathrm{K}$. In addition, a community-based study also showed that high vit $\mathrm{K}$ levels are associated with lower concentrations of circulating inflammatory markers, e.g., IL-6 ${ }^{[39]}$.

\section{Conclusion}

We approved a new protective role for vitamin $\mathrm{k}$ in rat model of ulcerative colitis, this suggests a potential therapeutic application in preventing oxidative damage and inflammatory cascade in patient with ulcerative colitis. We recommended vitamin $\mathrm{K}$ supplementation with advance of injectable form of this vitamin, in addition to diet containing vitamin $\mathrm{K}$ in patient with ulcerative colitis. Further studies and clinical trials are required to investigate the effect of vitamin $\mathrm{K}$ action in patient with inflammatory bowel disease.

\section{Declaration of interest statement}

The authors declare that there is no conflict of interests regarding the publication of this paper.

\section{Acknowledgment}

The authors are grateful to the members of Zagazig scientific and medical research center (ZSMRC) in Zagazig University, Egypt for its support. Moreover, we are thankful to Dr. Mona Mostafa Ahmed, Pathology Department, Faculty of Medicine, Zagazig University, for performing the histopatholgical studies.

\section{Ethical approval}

All animals received care according to the guide and ethical regulations for the care and use of laboratory animals according to Institute of Laboratory Animal Resources, all experimental procedures were approved and in accordance with the ethical standards of the Institutional Research Board of Zagazig University.

\section{Reference}

1 Cetinkaya, A.; Bulbuloglu, E.; Kantarceken, B.; Ciralik, H.; Kurutas, EB.; Buyukbese, MA.; Gumusalan, Y. Effects of L-carnitine on oxidant/antioxidant status in acetic acidinduced colitis. Dig Dis Sci., 2006, 51(3):488494. DOI: $10.1007 / \mathrm{s} 10620-006-3160-9$

2 Buffinton, GD.; Doe, WF. Depleted mucosal antioxidant defenses in inflammatory bowel disease. Free Radic Biol Med., 1995, 19 (6):911-918. DOI: $\underline{10.1016 / 0891-}$ 5849(95)94362-H

3 Koch, TR.; Yuan, LX.; Stryker, SJ.; Ratliff, P.; Telford, GL.; Opara, EC. Total antioxidant capacity of colon in patients with chronic ulcerative colitis. Dig Dis Sci., 2000, 45(9):1814-1819. [PMID: 11052325 DOI: 10.1023/a:1005517824877]

4 Cetinkaya, A.; Bulbuloglu, E.; Kurutas, EB.; Ciralik, H.; Kantarceken, B.; Buyukbese, MA. 
Beneficial effects of $\mathrm{N}$-acetylcysteine on acetic acid-induced colitis in rats. Tohoku $\boldsymbol{J}$ Exp Med., 2005, 206 (2):131-139. [PMID: 15888969 DOI: $10.1620 /$ tjem.206.131]

5 Burton, GW.;Joyce, A.;Ingold, KU. First proof that vitamin $\mathrm{E}$ is major lipid-soluble, chainbreaking antioxidant in human blood plasma. Lancet., 1982， 7; 2(8293):327. [PMID: 6124736 DOI: $10.1016 / \mathrm{s} 0140-6736(82) 90293-$

8]

6 Leone,V;Chang,EB.;Devkota,S. Diet,microbes, and host genetics: the perfect storm in inflammatory bowel diseases. J Gastroenterol., 2013;48 (3):315-321. [PMID: 23475322 DOI: 10.1007/s00535-013-0777-2]

7 Baumgart, DC.; Carding, SR. Inflammatory bowel disease: cause and immunobiology. Lancet., 2007, 12;369(9573):1627-1640. DOI: $\underline{\text { 10.1016/S0140-6736(07)60750-8 }}$

8 Mudter, J.;Neurath, MF. IL-6 signaling in inflammatory bowel disease: Pathophysiological role and clinical relevance. Inflamm Bowel Dis., 2007;13(8):10161023.DOI: $10.1002 / \mathrm{ibd} .20148$

9 Rovedatti, L.;Kudo, T.;Biancheri, P.;Sarra, M.; Knowles, CH.; Rampton, DS.; Corazza, GR.; Monteleone, G.; Di Sabatino, A.; Macdonald, TT. Differential regulation of interleukin 17 and interferon c production in inflammatory bowel. Gut., 2009, 58(12):1629-1636. [PMID: 19740775 DOI: 10.1136/gut.2009.182170]

10 Chen, Q.; Devine, I.; Walker, S.; Pham, H.; Ondrasik, R.; Patel, H.; Chau, WC.; Parker, W.; Kyle, D.; Bartol, Riahi S.; Mittal, A.; Barsotti, R.; Young, L. Nox2ds-Tat, A Peptide Inhibitor of NADPH Oxidase, Exerts Cardioprotective Effects by Attenuating Reactive Oxygen Species During Ischemia/Reperfusion Injury Am. J. Biomed. Sci., 2016, 8(3): 208-227. DOI: 10.5099/aj160300208

11 Agrawal, M.; Arora, S.;Li, J.;Rahmani, R.; Sun, L.; Steinlauf, AF.; Mechanick, JI.; Zaidi, M. Bone, inflammation, and inflammatory bowel disease. Curr Osteoporos Rep.,2011, 9 (4):251-257.DOI: $10.1007 / \mathrm{s} 11914-011-0077-9$

12 Khedr, NF.; Khedr, EG. Antioxidant and Antiinflammatory Effects of Curcumin on $\mathrm{CCl} 4$ induced Liver Fibrosis in Rats. Am. J. Biomed.
Sci. $\quad$ 2014, 6(3), 191-200.DOI: 10.5099/aj140300191

13 Allam MM. Insulin Like Growth Factor-1(IGF1) Promotes Angiogenesis and Reverses Ischemia Reperfusion Induced Acute Kidney Injury in Rats: Role of VEGF and TGF- $\beta 1 . \mathbf{A m}$. J. Biomed. Sci., 2016, 8(2), 160-168. DOI: 10.5099/aj160200160

14 Furie, B.; Bouchard, BA.; Furie, BC. vit Kdependent biosynthesis of gammacarboxyglutamic acid. Blood., 1999, 93 (6): 1798-1808. [PMID: 10068650]

15 Suttie, JW. vit K. In: Handbook of vitamins, New York and Basel: Marcel Dekker., 1991 pp 145-194.

16 Ohsaki, Y.; Shirakawa, H.; Hiwatashi, K.; Furukawa, Y.; Mizutani, T.; Komai, M. Vitamin K suppresses lipopolysaccharideinduced inflammation in the rat. Biosci Biotechnol Biochem., 2006, 70 (4):926-932. [PMID: 16636460]

17 Reddi, K.; Henderson, B.; Meghji, S.; Wilson, M.; Poole, S.; Hopper, C.; Harris, M.; Hodges, SJ. Interleukin 6 production by lipopolysaccharide-stimulated human fibroblasts is potently inhibited by naphthoquinone (vitamin $\mathrm{K}$ ) compounds. Cytokine., 1995, 7 (3) :287-290. [PMID: 7640347 DOI: $10.1006 /$ cyto.1995.0034]

18 Li, J.; Lin, JC.; Wang, H.; Peterson, JW.; Furie, BC.; Furie, B.; Booth, SL.; Volpe, JJ.; Rosenberg, PA. Novel Role of vit $K$ in Preventing Oxidative Injury to Developing Oligodendrocytes and Neurons. J Neurosci., 2003 ，23(13):5816-5826. [PMID: 12843286 DOI:10.1523/JNEUROSCI.23-13-05816.2003]

19 Eichbaum, FW.;Slemer, O.; Zyngier, SB. Antiinflammatory effect of warfarin and vit K1. Naunyn Schmiedebergs Arch Pharmacol., 1979, 307(2):185-190. DOI: 10.1007/bf00498462

20 Tahan, G.; Aytac, E.; Aytekin, H.; Gunduz, F.; Dogusoy, G.; Aydin, S.; Tahan, V.; Uzun, H. Vitamin $E$ has a dual effect of antiinflammatory and antioxidant activities in acetic acid-induced ulcerative colitis in rats, Can J Surg., 2011, 54(5): 333-338.[PMID: 21933527 DOI: $10.1503 /$ cjs.013610] 
21 Keshavarzi, Z.; Alikhani, V.; Vatanchia, M.; Tabatabaei, Yazdi, A.; Bibak, B.; Mohebbati, R. Effects of Aloe Vera Gel on Gastric Acid Secretion and Colon Histopathology in Ulcerative Colitis Model induced by Acetic Acid in Rats. J Adv Med Biomed Res., 2014, 22 (95): 1-11.

22 Morris, G.; Beck, PL.; Herridge, MS.; Depew, WT.; Szewczuk, MR.; Wallace, JL. Hapteninduced model of chronic inflammation and ulceration in the rat colon. Gastroenterology., 1989,96 (3):795-803.[PMID: 2914642]

23 Dieleman, LA.; Palmen, MJ.; Akol, H.; Bloemena, E.; Peña, AS.; Meuwissen, SG.; Van Rees, EP. Chronic experimental colitis induced by dextran sulphate sodium (DSS) is characterized by Th1 and Th2 cytokines. Clin Exp Immunol., 1998, 114 (3):385-391.DOI: 10.1046/j.1365-2249.1998.00728.x

24 Ohkawa, H.; Ohishi, N.; Yagi, K. Assay for lipid peroxides in animal tissues by thiobarbituric acid reaction. Anal Biochem., 1979, 95(2): 351-358. DOI: 10.1016/00032697(79)90738-3

25 Lowry, OH.; Rosebrough, NJ.; Farr, AL.; Randall, RJ. Protein measurement with the Folin phenol reagent. J Biol Chem., 1951, 193 (1):265-275. [PMID: 14907713]

26 Shahrokhi,N.;Keshavarzi, Z.;Khaksari Haddad, M.; Amirafzali, F.; Dabiri, S.;Shahrokhi, N. Protective effect of Mumiju against acetic acid-induced ulcerative colitis in rats. Avicenna J Phytomed., 2018, 8(5): 457-464. [PMID: 30345233 PMCID: PMC6190247]

27 Nemzer, BV.; Yashin, AY.; Yashin, YI. The Issues of Antioxidant Therapy. Am. J. Biomed. Sci., 2013, 5(2), 80-108. DOI: 10.5099/aj130200080

28 Carty, E.;De-Brabander, M.;Feakins, RM.; Rampton, DS. Measurement of in vivo rectal mucosal cytokine and eicosanoid production in ulcerative colitis using filter paper. Gut., 2000,46 (4); 487-492. DOI: 10.1136/gut.46.4.487

29 Chavan, S.; Sava, L.; Saxena, V.; Pillai, S.; Sontakke, A.; Ingole, D. Reduced glutathione: importance of specimen collection. Indian $\boldsymbol{J}$ Clin Biochem., 2005, 20 (1); 150-152. [PMID: 23105514 DOI: $10.1007 / \mathrm{BF} 02893062]$
30 Hodges, SJ.;Pitsillides,AA.;Ytrebø, LM.; Soper R. Anti-Inflammatory Actions of vit K. 2017. DOI: $\underline{10.5772 / 63891}$

31 Mourad, FH.;Barada, KA.; Saade, NE. Impairment of Small Intestinal Function in Ulcerative Colitis: Role of Enteric Innervation. J Crohns Colitis., 2017, 11(3) 369-377. DOI: 10.1093/ecco-jcc/jjw162

32 De Souza,HS.;Fiocchi, C.Immunopathogenesis of IBD: current state of the art. Nat Rev Gastroenterol Hepatol., 2016, 13 (1):13-27. DOI: $10.1038 /$ nrgastro.2015.186

33 Amit-Romach, E.; Reifen, R.; Uni, Z. Mucosal function in rat jejunum and ileum is altered by induction of colitis. Int $\mathbf{J}$ Mol Med., 2006, 18 (4):721-727. [PMID: 16964428]

34 Hollander, D.; Rim, E.; Ruble, PE Jr. Vitamin $\mathrm{K} 2$ colonic and ileal in vivo absorption: bile, fatty acids, and $\mathrm{pH}$ effects on transport. $\boldsymbol{A m} \boldsymbol{J}$ Physiol., 1977, 233(2): 124-129. [PMID: 18938 DOI: 10.1152/ajpendo.1977.233.2.E124]

35 Shea, MK.; Booth, SL.; Massaro, JM.; Jacques, PF.; D'Agostino, RB Sr.; Dawson-Hughes, B.; Ordovas, JM.; O'Donnell, CJ.; Kathiresan, S.; Keaney, JF J.; Vasan, RS.; Benjamin, EJ. Vitamin K and Vitamin D Status: Associations with Inflammatory Markers in the Framingham Offspring Study. Am J Epidemiol. 2008, 167 (3):313-320.DOI: 10.1093/aje/kwm306

36 Vereecke, L.; Sze, M.; Mc Guire, C.; Rogiers, B.; Chu, Y.; Schmidt-Supprian, M.; Pasparakis, M.; Beyaert, R.; van Loo, G. Enterocytespecific A20 deficiency sensitizes to tumor necrosis factor-induced toxicity and experimental colitis. J Exp Med., 2010, 207 (7):1513-1523. DOI: $\underline{10.1084 / j \mathrm{jem} .20092474}$

37 Dohi, T.; Ejima, C.; Kato, R.; Kawamura, YI.; Kawashima, R.; Mizutani, N.; Tabuchi, Y.; Kojima, I. Therapeutic potential of follistatin for colonic inflammation in mice. Gastroenterology., 2005, 128 (2):411-423. DOI: $10.1053 /$ j.gastro.2004.11.063

38 Nakajima, S.; Iijima, H.; Egawa, S.; Shinzaki, S.; Kondo, J.; Inoue, T.; Hayashi, Y.; Ying, J.; Mukai, A.; Akasaka, T.; Nishida, T.; Kanto, T.; Tsujii, M.; Hayashi, N. Association of vit K deficiency with bone metabolism and clinical disease activity in inflammatory bowel disease. 
Nutrition., 2011, 27 (10):1023-1028. [PMID: 21482072 DOI: 10.1016/j.nut.2010.10.021]

39 Ebina, K.; Shi, K.; Hirao, M.; Kaneshiro, S.; Morimoto, T.; Koizumi, K.; Yoshikawa, H.; Hashimoto, J. Vitamin K2 administration is associated with decreased disease activity in patients with rheumatoid arthritis. Mod Rheumatol., 2013, 23 (5):1001-1007. [PMID: 23124653 DOI: $10.1007 / \mathrm{s} 10165-012-0789-4]$

40 Okamoto, H.;Shidara, K.; Hoshi, D.;Kamatani, N. Anti-arthritis effects of vitamin K (2) (menaquinone-4)--a new potential therapeutic strategy for rheumatoid arthritis. FEBS J., 2007, 274 (17):4588-4594. [PMID: 17681015 DOI: $10.1111 / \mathrm{j} .1742-4658.2007 .05987 . \mathrm{x}]$

41 Ohsaki, Y.;Shirakawa, H.; Hiwatashi, K.; Furukawa, Y.; Mizutani, T.; Komai, M. Vitamin K suppresses lipopolysaccharideinduced inflammation in the rat. Biosci Biotechnol Biochem., 2006, 70 (4):926-932. [PMID: 16636460 DOI: 10.1271/bbb.70.926]

42 Suzuki, A.;Hanada, T.;Mitsuyama, K.;Yoshida, T.; Kamizono, S.; Hoshino, T.; Kubo, M.; Yamashita, A.; Okabe, M.; Takeda, K.; Akira, S.; Matsumoto, S.; Toyonaga, A.; Sata, M.; Yoshimura, A. CIS3/SOCS3/SSI3 plays a negative regulatory role in STAT3 activation and intestinal inflammation. J Exp Med., 2001, 193 (4):471-481.DOI: $\underline{10.1084 / \mathrm{jem} .193 .4 .471]}$
43 Terabe, F.; Fujimoto, M.; Serada, S.; Shinzaki, S.; Iijima, H.; Tsujii, M.; Hayashi, N.; Nomura, S.; Kawahata, H.; Jang, MH.; Miyasaka, M.; Mihara, M.; Ohsugi, Y.; Kishimoto, T.; Naka, T. Comparative analysis of the effects of antiIL-6 receptor $\mathrm{mAb}$ and anti-TNF $\mathrm{mAb}$ treatment on CD4(?) T-cell responses in murine colitis. Inflamm Bowel Dis., 2011, 17 (2):491-502. DOI: 10.1002/ibd.21384

44 Shea, MK.; Booth, SL.; Massaro, JM.; Jacques, PF.; D'Agostino, RB Sr.; Dawson-Hughes, B.; Ordovas, JM.; O'Donnell, CJ.; Kathiresan, S.; Keaney, JF Jr.; Vasan, RS.; Benjamin, EJ. Vitamin $\mathrm{K}$ and vitamin $\mathrm{D}$ status: associations with inflammatory markers in the Framingham Offspring Study. $\boldsymbol{A m} \boldsymbol{J}$ Epidemiol., 2008,167(3) :313-320. [PMID: 18006902 DOI: 10.1093/aje/kwm306] 